\title{
Pyrogenic Infection
}

National Cancer Institute

\section{Source}

National Cancer Institute. Pyrogenic Infection. NCI Thesaurus. Code C50719.

An infection caused by pus-producing organisms. 